\title{
Chemical experiment as a mean of implementation of the task-oriented approach in teaching chemistry in comprehensive educational institutions
}

\author{
A. K. Grabovyi \\ Bohdan Khmelnytsky National University of Cherkasy, Ukraine \\ Corresponding author. E-mail: graboviy_ak@ukr.net
}

Paper received 18.04.18; Accepted for publication 25.04.18.

\section{http://doi.org/10.31174/SEND-PP2018-163VI67-07}

\begin{abstract}
Abctract. The article clears up the theoretical and methodical principles concerning the use of a chemical experiment as a mean of implementation of the task-oriented approach in teaching chemistry in comprehensive education institutions. The essence of concepts of task, educational task was characterized. Examples of the use of a chemical experiment concerning the implementation of educational tasks in teaching chemistry in comprehensive educational institutions were given.

Keywords: chemical experiment; theoretical and methodical principles; task-oriented approach; task; educational task; chemistry; comprehensive educational institutions.
\end{abstract}

Introduction. At the modern stage of the development of pedagogical science and school practice, the problem of organizing educational activities of schoolchildren becomes of a particular importance. The significance of this problem is conditioned by radical changes that have occurred in the system of school chemical education. And this actualizes the problem of improving the content, forms and methods of organizing the educational activities of pupils in chemistry in comprehensive education institutions.

Short overview of publications on the subject matter. In the national methodology of teaching chemistry, the problem of organizing the activities of pupils is highlighted in the works of N. Burynska, L. Velychko, A. Grabovyi, N. Lukashova, O. Maksymov, V. Starosta, N. Chaichenko, O. Iaroshenko and others. The researchers examined the issues of the content, methods and forms of teaching chemistry in the period of formation, reformation and updating of school chemical education in Ukraine. Simultaneously, the problem of using a chemical experiment as a mean of implementation of the task-oriented approach in the educational process in chemistry in comprehensive education institutions requires further researches.

The purpose of the research consists in the highlighting the theoretical and methodical principles concerning the use of a chemical experiment as a mean of implementation of the task-oriented approach in teaching chemistry in comprehensive education institutions.

Presentation of the main research material. As a result of the analysis of literary sources, it was concluded that the educational activity of schoolchildren is a system of "mental and practical actions, the implementation of which ensures the mastering of knowledge, the mastering of abilities and skills of their application for solving various tasks" [5, p.94]. The object of the educational activity of pupils is the accumulated by mankind experience of cognition and transformation of the visual environment [4, p.17].

The educational activity of schoolchildren can be characterized on the basis of general and psychological theories of activity.

On the basis of the general theory of activity, the educational activity of schoolchildren is the aggregate of its main elements: object, subject, activity, means of activity, results [11]. Let's concretize the said elements of educational activity.

One of the essential peculiarities of educational activity is its two-sidedness, as well as the dual function of a pupil in educational activity: a pupil is not only the object of activity organized by the teacher, but also the subject, who actively carries out it [11, p.17].

Another peculiarity of educational activity is the manifestation of the activity of its subjects. Under the activity in pedagogy we understand the designation of the subject state associated with the performance of a certain action or communication.

Such element of activity, as means of training and tools, in the educational activity of schoolchildren is represented by a variety of teaching means. In teaching chemistry, along with well-known teaching tools are used specific chemical reagents and devices, without which it is impossible to carry out an experiment, to solve experimental tasks.

The completeness of educational activity, as well as other types of activities, is evidenced by its result. The result of educational activity is the knowledge and skills that are formed in the process of training. The comparison of the received and expected results, as notes O. Iaroshenko, - promotes not only the further organization of the educational process, but also the development of cognitive motivation of schoolchildren's teaching [12, p.17].

The psychological theory of activity introduces new units of its analysis - motives, educational task, educational actions, actions of control and evaluation [4, p.19]. Let's analyze the said components of educational activity.

While carrying out any type of activity the content characteristic of the activity process, the importance of activity for the subject is conditioned by the aggregate of motives. As certifies the analysis of literature, the motives of educational activity of schoolchildren are diverse and ambiguous. They interweave cognitive motives that are connected with the content of teaching and the process of its implementation, and social motives conditioned by different social interactions of schoolchildren. $\mathrm{G}$. Shchukina distinguishes the following groups of motives: social, cognitive, moral, motives of communication [11, p.50].

Analyzing the psychological content of the concept of "task", G. Ball notes that the term task can be used to designate objects that belong to three different categories: 
1) to the category of the purpose of the subject's actions, the requirements, that are put before the subject; 2) to the category of situation, which includes along with the purpose - the conditions in which this purpose must be achieved; 3 ) to the category of verbal formulation of this situation [1, p.76].

In the case of evaluation of the task as educational Iu. Mashbyts indicates the need to take into account its place and correlation with the purpose (purposes) of educational activity [8, p.77]. In this approach, the term "educational task" is used for the definition of three different categories of tasks: 1) tasks (purposes) of teaching; 2) educational tasks, or "didactic tasks", which are set by a teacher; 3) tasks that are given to pupils in order that their solution provides for the teaching purposes achievement [7, p.59].

G. Ball emphasizes that didactic tasks are solved by a teacher (lecturer) [2, p.143], and educational tasks are a mean of achieving educational purposes [9, p.62].

V. Guzeev under the task understands the diagnostically and operationally set purpose. The purpose is diagnostic if there are available means of objective check of its purpose. The purpose is set operationally, if the formulation indicates the means of its achievement [3, p.29].

Continuing the research, let's note that the educational material provided by the program and reflected in the textbook content, is included in the structure of schoolchildren's activities in the form of educational tasks, the choice of which is determined by the peculiarities of cognition and the very structure of their cognitive activity. Therefore, all educational activity of schoolchildren focuses on solving of educational tasks, which are gradually complicated by the content and methods of cognitive actions necessary for their solution [9, p.9].

The structural elements of educational activity include educational activities. As O. Leontiev notes, "the activity consists of a set of actions" [6, p.102]. They are inseparable from educational tasks. The aggregate and the sequence of actions are not permanent, but depend on the purpose and the content of educational task, the formation of reflective operations of pupils, their age peculiarities.

The completeness of the educational action is evidenced by its result. And in order to fix it, it is necessary to perform evaluation and control actions. They allow you to determine the correspondence of the result of educational actions to the end purpose. The feedback confirms the correctness or error of the process and the result of teaching, and thus motivates pupils for actions correction. Along with pupils, the actions of control and evaluation of the results of educational activity are also carried out by the teacher.

As a result of the analysis of literary sources, it was concluded that the introduction of a new unit of analysis of educational activity - educational task - contributes to the change, restructuring, enrichment of the very child [4, p.18]. From a passive consumer of knowledge, the pupil is transformed into an active subject of educational activity. And the teacher ceases to play the role of information translator. His new functions are setting tasks for organizing the pupils' activities, managing the purpose of the activity and expertise of the obtained results for the subject of compliance with the planned one [3, p.14].
Continuing the research, we will focus on the implementation of the task-oriented approach with the help of a chemical experiment in the study of chemistry in comprehensive education institutions.

According to the purpose of the educational branch "Natural Science" and its chemical component, defined in the new edition of the State standard for basic and complete general secondary education, the teaching of chemistry in school is aimed at the development of the means of the subject of the pupils' personality, the formation of their culture, subject and key competences, to develop experimental abilities and skills of pupils.

In view of this, we characterize the process of forming experimental abilities and skills from the position of the task-oriented approach. For example, we use the formation of pupils' skills to prepare solutions with a certain mass fraction of the dissoluble substance. The formation of these skills takes place in the $7^{\text {th }}$ form. The State requirements for the level of comprehensive educational training of pupils in the program provide that the pupil distinguishes the solvent and the dissoluble substance, prepares the solution with a mass fraction of the dissoluble substance [10, p.11-12].

The process of forming skills and abilities of pupils in chemistry in practice is divided into three stages: preparatory, synthetic and final.

At the preparatory or analytical stage, the pupils are acquainted with the rules of work, separation and comprehension of each operation, the actions are performed as a result of the great efforts of consciousness. At this stage, there are a lot of erroneous actions.

At the synthetic stage, separate operations are merged into one whole, arises the necessary coordination of actions. Pupils, knowing certain rules of the work, carry out certain operations, but do so with a great effort of consciousness, their actions are not brought to automatism.

At the final stage, in the consequence of multiple operations, the actions become automatic, unnecessary movements disappear, the work passes calmly.

The practice convinces that the most successful practical abilities and skills in chemistry are formed under the following conditions:

1) at the beginning of the formation, separate skills should be divided into small operations;

2) the teacher explains the order of execution of all operations and shows how to do it;

3) the teacher verifies whether the pupils understood him correctly;

4) it is sometimes helpful to give drawings during explanation, which clarify the separate aspects of the performed operation;

5) the teacher warns the pupils about those mistakes, which may occur in the process of operations execution.

While preparing for the lesson, the teacher defines the following types of educational tasks: 1) didactic: on the basis of the concept about the composition of the solution, the mass fraction of the dissoluble substance to form the knowledge and ability to prepare solutions with a certain mass fraction of the dissoluble substance; 2) the target task of teaching pupils: to acquire abilities and skills to prepare solutions with a certain mass fraction of the dissoluble substance; 3) tasks-exercises on the application of acquired knowledge and skills. 
The teacher begins the study of the subject with the actualization of basic knowledge about what is a solution and what are its components, a mass fraction of the dissoluble substance. Pupils are offered to solve the task concerning the calculation of the mass of the dissoluble substance in a given solution with a certain mass fraction. Then the teacher reveals the significance of the solutions in human practice and motivates the pupils' activity to acquire the skills to prepare solutions with a certain mass fraction of the dissoluble substance.

The technique of making a solution the teacher clears up using the method of algorithmic instructions. Before making a solution of salt with a certain mass fraction of the dissoluble substance in the creative aggregate state, it is necessary: 1) to calculate the mass of the dissoluble substance and the mass of the solvent; 2) weigh the dissoluble substance; 3) transfer the substance into a glass; 4) measure the required volume of solvent - water; 5) add water to the dissoluble substance; 6) mix the components before the formation of a homogeneous solution [13, p.161-162].

To make a solution with a certain mass fraction of the dissoluble substance, are necessary: a substance for dissolution, a vessel for preparing the solution, a glass stick for concitation, scales, diameters, measuring dishes.

Then the teacher demonstrates the preparation of the solution on a concrete example.

At the beginning, the teacher, demonstrating experiments, pays attention to the actions he carried out and calls them. He pays attention to the phenomena that occur with it and also calls them. Then the teacher suggests to separate pupils to describe everything that the teacher has done and what happens with it. The rest of the pupils also observe, make corrections and additions.

Task. Prepare the solution of kitchen salt (sodium chloride) with the mass of $120 \mathrm{~g}$ with a mass fraction of the dissoluble substance $15 \%$.

$$
\begin{array}{l|l}
\begin{array}{l}
\text { Given: } \\
\mathrm{m}(\mathrm{NaCl})=120 \mathrm{~g} \\
\mathrm{w}(\mathrm{NaCl})=15 \%
\end{array} & \begin{array}{l}
\text { Resolution } \\
1 . \text { Calculate the mass of kitchen salt: } \\
\mathrm{m}(\mathrm{NaCl})-? \\
\mathrm{~m}\left(\mathrm{H}_{2} \mathrm{O}\right)-?
\end{array} \\
w(\mathrm{NaCl})=\frac{m(\mathrm{NaCl})}{m(\text { solution } \mathrm{NaCl})} \cdot 100 \% \\
\\
w(\mathrm{NaCl})=\frac{m(\text { solution } \mathrm{NaCl}) \cdot w(\mathrm{NaCl})}{100 \%} \\
100 \%
\end{array}
$$

2. Calculate the mass of water:

$$
\mathrm{m}\left(\mathrm{H}_{2} \mathrm{O}\right)=120 \mathrm{~g}-18 \mathrm{~g}=102 \mathrm{~g}
$$

$\mathrm{V}\left(\mathrm{H}_{2} \mathrm{O}\right)=102 \mathrm{~g} \times 1 \mathrm{~g} / \mathrm{ml}=102 \mathrm{ml}$

3. Weigh out on the scales the kitchen salt with the mass of $18 \mathrm{~g}$.

4. Place the salt in a glass of $120 \mathrm{ml}$ volume.

5. Measure with the measuring cylinder the water with the volume of $102 \mathrm{ml}$.

6. Carefully pour the water into a glass with the salt.

7. Stir the mixture with a glass stick until receiving a homogeneous solution.

During the demonstration of the experiment, the pupils resolve the auxiliary educational tasks.

1. How to correctly weight the solid?
2 How to properly measure the necessary volume of water?

3. What accelerates the solubility of many solids?

The pupils carry out the control actions during exercises performance.

1. Establish the sequence of actions for preparing a solution with a certain mass fraction of the dissoluble substance:

A mixing the dissoluble substance and water.

B calculation of the mass of the dissoluble substance and the solvent.

$\mathrm{B}$ mixing the formed mixture.

$\Gamma$ weighing a portion of the dissoluble substance and measuring the volume of water.

2. Indicate what is the unnecessary in the list of dishes and accessories necessary for the preparation of solutions: measuring cylinder, ruler, chemical glass, scales, laboratory tripod, retort, glass stick.

3. Prepare an aqueous solution of sugar with the mass of the dissoluble substance of $8 \%$, taking for this purpose the water with the volume of $140 \mathrm{ml}$.

The completeness of educational activity takes place in the practical work "Preparation of a solution with a certain mass fraction of the dissoluble substance". The mark given by the teacher for the report, allows you to determine the conformity of the result of the educational actions to the end purpose.

In addition to the task of forming experimental skills and abilities at the pupils, the teacher needs to solve the tasks aimed at improving the methodology of organizing and conducting laboratory experiments. The practice proves that the main directions of improving the methodology of organizing and conducting laboratory experiments are: 1) strengthening the research function of the experiment; 2) using the group form of the experiment; 3 ) using the individually differentiated tasks.

As an example of group work, the pupils of the $8^{\text {th }}$ form perform the laboratory experiments on the study of the properties of insoluble in water bases.

Subject. Interaction of insoluble bases with acids.

Purpose. Learn the reactions between insoluble bases and acids.

1. Verify whether the insoluble bases react with acids.

The first pupil works with $\mathrm{Cu}(\mathrm{OH})_{2}$ and $\mathrm{HNO}_{3}$

The second pupil works with $\mathrm{Fe}(\mathrm{OH})_{3}$ and $\mathrm{HNO}_{3}$

The third pupil works with $\mathrm{Cu}(\mathrm{OH})_{2}$ and $\mathrm{H}_{2} \mathrm{SO}_{4}$

The fourth pupil works with $\mathrm{Fe}(\mathrm{OH})_{3}$ and $\mathrm{HCl}$.

Verify the experiments results one by one and make the general conclusion.

2 . Find out the essence of the reactions between insoluble bases and acids.

Make up the equation of the reaction and write the names under all the substances involved in it. Make the general conclusion.

Conclusions. The theoretical analysis of the literature on the research issue revealed that the problem of the task-oriented approach in teaching chemistry in comprehensive education institutions is actual, but little examined. One of the factors in the implementation of the taskoriented approach in teaching chemistry is a chemical experiment. It can be regarded as a pedagogically expedient system of cognitive tasks. 


\section{ЛІТЕРАТУРА}

1. Балл Г. А. О психологическом содержании понятия «задача» /Г. А. Балл // Вопросы психологии. - 1970. - №6. C.75-85.

2. Балл Г. А. Теория учебных задач: психологопедагогический аспект / Г. А. Балл. - М. : Педагогика, 1990. - $184 \mathrm{c}$.

3. Гузеев В. В. О системе задач и задачном подходе к обучению / В. В. Гузеев // Химия в школе. - 2001. - №8. - С.1218.

4. Давыдов В. В. Концепция учебной дятельности / В. В. Давыдов, А. К. Маркова // Вопросы психологии. 1981. - №6. - С.13-27.

5. Кирсанов А. А. Индивидуализация учебной деятельносты как педагогическая проблема / А. А. Кирсанов. - Казань : Изд-во Казанского ун-та, 1982. - 224 с.

6. Леонтьев А. Н. Деятельность. Сознаний. Личность. / А. Н. Леонтьев. - М. : Политиздат, 1977. - 304 с.

7. Машбиц Е. И. Психологический анализ учебной задачи / Е. И. Машбиц // Советская педагогика. - 1973. - №2. C.58-65.

8. Машбиц Е. И. Психолого-педагогические проблемы компьютеризации обучения / Е. И. Машбиц. - М. : Педагогика, 1988. - $192 \mathrm{c.}$

9. Сохор А. М. Логическая структура учебного материала / А. М. Сохор. - М. : Педагогика, 1974. - 192 с.

10. Хімія, 7-9 кл. : навч. програма для загальноосвіт. навч. закладів (2015) [Електронный ресурс]. Режим доступу: http://mon.gov.ua/activity/education/zagalnaserednya/navchalni-programy.htlm

11. Щукина Г. И. Активизация познавательной деятельности учащихся в учебном процессе / Г. И. Щукина. - М. : Просвещение, $1979 .-160 \mathrm{c}$.

12. Ярошенко О. Г. Проблеми групової навчальної діяльності школярів: дидактико-методичний аспект / О.Г. Ярошенко. - К. : Станіца, 1990. - 245 с.

13. Ярошенко О. Г. Хімія : підруч. для 7 кл. загальноосвіт. навч. закладів / О. Г. Ярошенко. - Харків: СИЦІЯ, 2016. $192 \mathrm{c}$.

\section{REFERENCES}

1. Ball G.A. About psychological content of the concept of "task" /G. A. Ball // Issues of Psychology. - 1970. - No. 6. P.75-85.

2. Ball G. A. Theory of educational tasks: psychologicalpedagogical aspect / G. A. Ball. - M. : Pedagogy, 1990. - 184 p.

3. Guzeev V. V. About the system of tasks and the task-oriented approach to study / V.V. Guzeev // Chemistry in school. 2001. - No. 8. - P.12-18.

4. Davydov V. V. Concept of educational activity / V. V. Davydov, A. K. Markova // Issues of Psychology. - 1981. - No. 6. - P.13-27.

5. Kirsanov A. A. Individualization of educational activity as a pedagogical problem / A. A. Kirsanov. - Kazan: Editing House of Kazan University, 1982. - 224 p.

6. Leontiev A. N. Activity of consciousness. Personality. / A. N. Leontiev. - M. : Politizdat, 1977. - 304 p.

7. Mashbits E. I. Psychological analysis of educational task / E. I. Mashbits // Soviet Pedagogy. 1973. - No. 2. - P.58-65.

8. Mashbits E. I. Psychological-pedagogical issues of computerization of education / E .I. Mashbits. - M. : Pedagogy, 1988. $192 \mathrm{p}$.

9. Sokhor A. M. Logical structure of educational materials / A. M. Sokhor. - M.: Pedagogy, 1974. - 192 p.

10. Chemistry, the 7-9 forms.: educational program for comprehensive educational institutions (2015) [Electronic resource]. Access regime: http://mon.gov.ua/activity/education/zagalnaserednya/navchalni-programy.htlm

11. Shchukina G. I. Actualization of cognitive activity of pupils in educational process / G. I. Shchukina. - M. : Education, 1979. $-160 \mathrm{p}$.

12. Iaroshenko O. G. Problems of group educational activity of schoolchildren: didactical and methodical aspect / O. G. Iaroshenko. - K. : Stanitsa, 1990. - 245 p.

13. Iaroshenko O. G. Chemistry: manual for the $7^{\text {th }}$ form of comprehensive educational institutions / O. G. Iaroshenko. Kharkiv: SITSIA, 2016. -192 p.

Химический эксперимент как средство реализации задачного подхода в обучении химии в общеобразовательных учебных заведениях

А. К. Грабовый

Аннотация. В статье освещаются теоретико-методические основы использования химического эксперимента как средства реализации задачного подхода в обучении химии в общеобразовательных учебных заведениях. Раскрыта сущность понятий задача, учебная задача. Приведены примеры использования химического эксперимента в реализации учебных задач при обучение химии в общеобразовательных учебных заведениях.

Ключевые слова: химический эксперимент, теоретико-методические основы; задачный подход; задача; учебная задача; химия; общеобразовательные учебные заведения. 